\title{
Embodied Cognition Anchors Translating
}

\author{
Wang Bin \\ College of Foreign Languages, University of Shanghai for Science and Technology, Shanghai, China
}

Copyright $@ 2015$ Horizon Research Publishing All rights reserved.

\begin{abstract}
This paper aims to explore how cultural embodiment helps translators to make decisions in their understanding and translating. This approach will be based on the premise that cultural embodiment helps the translator to associate each understanding of source text with a detailed socio-cultural environment and gives rises to the translator on, what cultural perspectives he or she will take, and how to construct meaning in translation as well. Embodied cognition is a dynamic process, yet conventional and unique representations in language anchor reading and translating in some way.
\end{abstract}

Keywords Embodiment, Culture, Cognition, Translating

For some years now, translation studies have been concerned with cultural and cross cultural aspects of translation. In this context, interest has also grown in cultural embodiment and translating as a process for their successful transfer.

Shihui Han and Georg Northoff [2] believe that our brains and minds are shaped by our experiences, which mainly occur in the context of the culture in which we develop and live. Although psychologists have provided abundant evidence for diversity of human cognition and behavior across cultures, the question of whether the neural correlates of human cognition are also culture-dependent is often not considered by neuroscientists. However, recent trans-cultural neuroimaging studies have demonstrated that one's cultural background can influence the neural activity that underlies both high- and low-level cognitive functions. The findings provide a novel approach by which to distinguish culture-sensitive from culture-invariant neural mechanisms of human cognition.

However, rather than view cultural embodiment in terms of the difficulty it poses to the translator, this paper aims to explore how cultural embodiment helps translators to make decisions in their understanding and translating. Translating procedure, as a linguistic phenomenon, consists of two-way processes, understanding source text and representing in target language. They are all cognitive endeavors covered by cognitive linguistic studies. Embodied cognition is a key concept in translation studies as well as cognitive linguistics.

\section{Embodied Cognition}

Cognitive linguistics believes that linguistic structure represents conceptual structure mapped from our experience(s). In reading or understanding language, people process through digesting their acquired knowledge (stored or live experience). This is called embodied cognition. The relation between language and communicated event is that of a representation. However, this relation is very dyadic and egocentric, showing intrapersonal relation between languages and thought only. If embodied cognition stops here, it fails to explain why language can be used as a communicative tool.

Based on the fact that communication among people, of the same culture and different cultures, never stops, and people can always understand their counterparts in a way, it shows that language must contain another interpersonal relation, an imitative relation on shared human experience. In language communication, people are apt to adjust their psychological construction with their counterparts through providing and adopting different embodiment. When Peter told Dennis the other day that:

\section{SANDY KILLED MANY PEOPLE.}

Dennis responded: GOT ARRESTED?

Peter said: NO. YOU CAN'T CATCH A HURRICANE. Dennis said: I SEE.

In understanding Peter's words, Dennis took Sandy as a person at first. The embodied cognition is that of homicide. Dennis's response GOT ARRESTED shows that he was not on the same track with Peter. So Peter pulled Dennis back to his weather destruction. I SEE shows that Dennis adopted Peter's intended communicated event and set up new psychological construction at once to feed back that he knew what Peter meant. And when Peter heard I SEE, he knew that Dennis knew SANDY was a hurricane rather than a person and was on his track.

Language can work as a communicative means and mend up interrupted dialogue easily because it offers accessibility for the speakers to trigger out their shared embodied cognition, make their adjustments, and build up their re-embodiment.

So language possesses triadic attributes (intrapersonal and interpersonal) in communication: convention, representation 
and accessibility.

\section{Linguistic Meaning: Yield of Embodied Cognition}

In China, we often say 橘在淮南为橘, 在淮北为枳 (jú zài Huáinán wéi jú, zài Huáiběi wéi zhǐ ). Literally, it means when tangerine trees grow up in the middle part of Anhui Province, they yield tangerines, when transplanted to the north part of Anhui province, they yield trifoliate oranges. Metaphorically, it shows that things will turn out differently in different localities or surroundings.

What do I need to know in order to understand (1), which has been uttered by, say, Jack? Minimally, I would need to know the social facts (2)-(7).

(1) John kissed Mary.

(2) The word kiss means KISS.

(3) The words John and Mary are names of a male and a female human being, respectively.

(4) The word order shows that John kissed Mary, rather than vice versa.

(5) The past tense signifies that event described occurred sometimes in the past relative to the time of utterance.

(6) The sentence (normally) expresses an assertion.

(7) The names John and Mary actually refer to individual $\mathrm{X}$ and $\mathrm{Y}$.

But this is not enough to guarantee that I understand Jack. Imagine that I know (2-7), but Jack, who has had a rather idiosyncratic upbringing, thinks that kiss means HIT-ON-THE-HEAD. I will then fail to understand the meaning of (1) as meant by Jack. So I must also know that Jack knows (2-7). Furthermore, I must know, or at least assume, that Jack knows that I know (2-7). For if Jack thinks that I have had a strange upbringing, or maybe as a foreigner, I do not have a proper command of English, then he may not be using (1) in its conventional way, even though he knows (2-7). If this seems far-fetched, consider only (7), which involves not the meaning of the names John and Mary but their reference. Here it is easier to see that unless Jack and I can be quite sure not only that both of us know who the names refer to in this context, but that Jack knows that I know, and I know that Jack knows, there might be a misunderstanding. For instance, I am thinking of Mary Smith, and Jack is thinking of Mary Smith. But if I don't know that Jack knows that I am thinking of Mary Smith rather than Mary Ferguson, then I couldn't be sure who he is really referring to by Mary in uttering (1).

It is crucial to remember that this knowledge is conventional normative, in the sense that one can be right or wrong according to public criteria of correctness, in one's use of these conventions. When a speaker performs a speech act, he imposes his intentionality on those symbols. When you are in Rome do as Romans do.

If this KISS happened in China, say, Zhang Ming kissed Li Ping, HIT-ON-THE-HEAD will never be included in any understanding. For, traditionally, KISS means
MOUTH-TO-MOUTH touching, and confines to man and wife in their privacy only. That's why courtesy kissing was always a strange picture in China when its door was smashed open and more westerners came in to do the kissing show in public. Even today, when Chinese people read John kissed Mary, they would still prefer to treat them as man and wife, rather than any other relations.

\section{Embodied Cognition Perspectivizes Text Reading and Translating}

横看成岭侧成峰, 远近高低各不同。

(Héng kān chéng lǐng cè chéng fēng, yuănjìn gāodī gèbùtóng)

不识庐山真面目, 只缘身在此山中。

(Bùshi Lú Shān zhēn miàn mù, zhī yuán shēn zài cǐ Shān zhōng)

$$
\text { 苏轼《题西林壁》(sūshì tí xī lín bì ) }
$$

Literally in English:

It's a range viewed in face and peaks viewed from the side, Assuming different shapes viewed from far and wide.

Of mountain Lu we cannot make out the true face,

For we are lost in the heart of the very place.

(Xǔ Yuānchōng, [8]:193)

After visiting Lú Shān, a scenic spot in Jiangxi province, Sūshì, a well-known Chinese poet in Song dynasty, wrote this little poem to show his impression. He illustrates in the poem that people are very biased in understanding what they have seen. Embodiment produces perspectives (aspectual shapes). So is the case with language understanding and translating.

曹雪芹 ( cáo xuěqín) metaphorizes his writing $A$ Dream of

Red Mansions in a poem:

满纸荒唐言, 一把辛酸泪!

(măn zhǐ huāng táng yán, yī bă xīn suān lèi )

都云作者痴, 谁解其中味?

(dōu yún zuòzhě chī, shéi jiě qízhōng wèi)

And this poem has been translated in different versions by one Chinese translator Yang and two non-Chinese translators Hawkes and Joly respectively in the following:

Pages full of fantastic talks

Penned with bitter tears;

All men call the author mad,

None his message hears. (Yang, [9])

Pages full of idle words

Penned with hot and bitter tears:

All men call the author fool;

None his secret message hears. (Hawkes, [3])

Pages full of silly litter,

Tears a handful sour and bitter;

All a fool the author hold,

But their zest who can unfold? (Joly, [6]) 


\subsection{Perspectivized Image Schema}

Obviously, the three versions diversify in image schemas. See the following ISD diagram.

Diagram 1. Image schema diversification (ISD)

\begin{tabular}{|c|c|c|c|c|}
\hline 曹雪芹 & 荒唐言 & 一把辛酸泪 & 痴 & 解味 \\
\hline Yang & $\begin{array}{c}\text { fantastic } \\
\text { talks }\end{array}$ & bitter tears & mad & message hears \\
\hline Hawkes & $\begin{array}{c}\text { idle } \\
\text { words }\end{array}$ & $\begin{array}{c}\text { hot and bitter } \\
\text { tears }\end{array}$ & fool & $\begin{array}{c}\text { secret message } \\
\text { hears }\end{array}$ \\
\hline Joly & silly litter & $\begin{array}{c}\text { handful sour and } \\
\text { bitter (tears) }\end{array}$ & $\begin{array}{c}\text { All a } \\
\text { fool }\end{array}$ & zest unfold \\
\hline
\end{tabular}

Among them, versions with Chinese perspective are fantastic talks, handful sour and bitter (tears), mad, and secret message hears. The rest are in non- Chinese perspective. Perspective representing cultural memes (Blackmore [1]), is not confined to a person in a culture only. Translators may take perspectives of any culture in reading and translating. Handful sour and bitter tears by Joly, and secret message hears by Hawkes, the two non- Chinese translators' versions, show a typical Chinese perspective in reading and translating. While "idle words", "silly litter", "fool" and "all a fool" diverge from source text too much, because both Hawkes and Joly took the related words by their face values and failed to understand that Chinese writers usually degrade their writings to show modesty and respect to readers. 荒唐言 fantastic talks are not "idle words" nor "silly litter" at all. 痴 person completely involved is not "a fool" nor "all a fool" in any way. Or, maybe, both of them just wanted to have their personal or cultural understandings and translations.

Interestingly, Hawkes embodies his personal feelings in 辛酸泪 as “ hot and bitter tears", tears out of body are usually hot, trying to trace Cao's mentality. Yet Joly unfolds, wrongly, Cao's thousands of bitter metaphors in Hung Lou Meng, The Dream of the Red Chamber into vigorous and enthusiastic enjoyment (zest), and transfers OTHER VIEW (all men call the author mad 都云作者痴) into an EGO VIEW（All a fool the author hold 自状总是痴）. Different embodiment in reading produces different image schemas.

\subsection{Perspectivized Syntax}

Yang's and Hawkes' versions mirror source text, almost literally, in sentence order, in TALKS-TEARS-MAD-MESSAGE. Yang parallels lines 3, 4 with lines 1, 2 by putting latter in one sentence and former in another sentence with a comma break. While Hawkes believes that lines 3 and 4, a complete sentence with a semicolon break, should be a further explaining of lines 1 and 2, a complete sentence ending with a colon. Both of them think that lines 1 and 2 form one conceptual structure: TALKS ARE TEARS. Joly parallels later two lines, comma in middle, with first two lines, comma in middle, by a semicolon break, and ends with a question mark sticking to the source text. He understands that Cao shot the target with 4 separate arrows in two rounds with double ones in each.

Both Young's and Hawkes' versions end-rhymed ABCB, while Joly's version end-rhymed AABB.

Different embodiment makes different sentence patterns in translating.

\section{Embodied Cognition Integrates Mimetic Schemas in Translating}

Jordan Zlativ [10] believes that it is bodily mimesis, or mimetic schema that helps embodiment to be mapped onto language structures, and makes it possible for language to perform as a communicative tool. Mimetic schemas can be used either dyadically (in thought) or triadically (in communication). Mimetic schemas are experiential: each schema has a different emotional-proprioceptive "feel", or affective tone to it. For example, consider the affective contrast between the mimetic schemas KICK and KISS. Thus, mimetic schemas can be regarded as an important aspect of phenomenological embodiment. Mimetic schemas are representational: the "running" of the schema is differentiated from the "model event" which is represented unlike the most common explication given to "image schemas" (Johnson [5]). Mimetic schemas are, or at least can be pre-reflectively shared: since my and your mimetic schemas derive from imitating culturally salient actions and objects, as well as each other, both their representational and experiential content can be "shared" - though not in the strong sense of being known to be shared in the manner of (true) symbols or conventions.

Translating is, of course, a particular act of cognition and communication, featuring interlingually, and performs act of bodily mimesis for its cross-cultures where source language and target language, in some cases, do not share conventional communicative modes (Wang [7]). Translators integrate their translating through mimetic representation, communicative sign function, volition and cross-modality.

\subsection{Representation Integration}

Translating, as interlingual communication, negotiates among diversified cultural conventions. Although semantic structure carries conventional communicative mode of a culture, yet presented event differentiates in the running. It is bodily mimesis that helps translators to extract conceptual structure (embodied cognition) from semantic structure of source text and transfer it to target semantic structure, and the relation between them could be one to many even within a single language. For instance:

Diagram 2. From semantic structure to conceptual structure

\begin{tabular}{|c|l|}
\hline Semantic structure & $\begin{array}{l}\text { a, It's good for you to do so. } \\
\text { b. A rolling stone gathers no moss. }\end{array}$ \\
\hline Conceptual structure & $\begin{array}{l}\text { a(1) It's good for you to do so. } \\
\text { a(2) It's good for you to do so. } \\
\text { b(1) You'll learn less by frequent job changes. } \\
\text { b(2) Jogging helps keep fit. }\end{array}$ \\
\hline
\end{tabular}


Diagram 3. From conceptual structure to semantic structure

\begin{tabular}{|c|l|}
\hline \multirow{2}{*}{ Conceptual structure } & $\begin{array}{l}\text { a, Love is war. } \\
\text { b, Anger is fire. }\end{array}$ \\
\hline \multirow{5}{*}{ Semantic structure } & $\begin{array}{l}\text { a(1) He is known for his many rapid } \\
\text { conquests. } \\
\text { a(2) He fled from her advances. } \\
\text { a(3) He is slowly gaining ground with her. } \\
\text { b(1)Those are inflammatory remarks. } \\
\text { b(2) He was breathing fire. } \\
\text { b(3) He was consumed by his anger. }\end{array}$ \\
\hline
\end{tabular}

It's embodied cognition that helps translators to pin down pragmatic function of, say, It's good for you to do so. Suppose, Benjamin played truant two weeks ago, and his father gave him a copy of David Copperfield, then a week later, the father saw him reading Gulliver's Travel on the bench in back yard and patted on his head saying it's good for you to do so. Chinese translators would translate into 你 能这么做真好(It's good for you to do so), for the father didn't expect his son making progress so fast. If the father greeted his neighbor jogging passing by in the morning, saying, it's good for you to do so. Then Chinese version would be 这么做对你有好处 (It's good for you to do so). Family education and morning greeting are there in any culture. The same experience helps translators build up logical gestalt structure and make right judgment through recontextualization. For they would do the same things in their daily lives. Embodiment filters out a proper communicative mode from source semantic structure and helps embed the same mode in a chosen adjusted target semantic structure, for neither of Chinese versions would be read in an arbitrary way.

So is the case with Xǔ Yuānchōng's translation of Sū Shì's Tí Xĩ Lin Bì. Sū Shì embodies, in the poem, in eye (横看成岭 侧成峰), face (不识庐山真面目) and body(只缘身在此山 中). Xǔ Yuānchōng, in translation, not only transfers but also transforms the embodiment:

Diagram 4. Embodiment transferring and transforming 横看成岭侧成峰,

It's a range viewed in face and peaks viewed from the side, 远近高低各不同。

Assuming different shapes viewed from far and wide. 不识庐山真面目,

Of mountain Lu we cannot make out the true face, 只缘身在此山中。

For we are lost in the heart of the very place.

Xǔ transfers "eye" and "face" to English version, but transforms "body" into "we", and personifies 此山中 into " in the heart". Check the marked parts respectively in diagram 4. Bodily mimesis helps translator build up an imitative representation system in target language from Other communicative mode and makes the translated version more adaptive to target language readers. For "we" are "bodies". 此山中 literally means "in the mountainous area", and "in the heart" can indicate "in the circumstance" too. The possibility for so doing lies in the shared embodied cognition. It consumes no cognitive efforts for any readers to connect "in the area" with "in the heart", for we are thinking metaphorically. Categorically, "in the area" indicates literally " in any part of the area" while " in the heart" means metaphorically "in the central part of the area", but they share overlapped part and are still in the same cognitive domain. Metonymically, it's easy for different languages to get accessed to different related parts of a cognitive mental space. English readers will not misunderstand "pearl in palm (掌上明珠)" in the place of “ apple of an eye" when they hear a father's cherishing his daughter " she is a glorious pearl in my palm".

Sū Shì's Tí Xī Lín Bì is a philosophical poem indicating that man's view is always an embodied vision. He illustrated this idea through demonstrating from changing physical views of a mountain to different mental visions of recognition by 4 paralleled sentences with 7 Chinese characters in each, but never depicted this theme in any physical form.

Creatively, Xǔ translated the poem in an overt physical form by continued compressed sentence length indicating an inductive procedure from physical perception (different shapes) to mental conception (the true face lost in the heart), a typical embodied cognitive process. His personal embodied understanding of the poem gives rise to the communicative mode of compressed sentence length and helps him to integrate semantic structure with conceptual structure through deducing from more to less. The idiomatic usage of "from far and wide" instead of " near and far, high and low (远近高低)" shows his domestication perspective in translating.

\subsection{Communicative Sign Functions Integration}

Can you imagine what English word "meow" and Dutch word "miauw" related to? In Hebrew the same word is "miyau". In Finnish, German, Hungarian and Italian, the word is "miau". By now you have probably guessed that these words are all translations of English "meow". They all seem to simply describe the same noise, just with different spellings. But it is not true, however, for the onomatopoeic word that describes the noise a cat makes when it is happy, different languages sound in various ways:

Diagram 5. Cat's sound

\begin{tabular}{|c|c|c|c|c|}
\hline Danish & English & Finnish & French & German \\
\hline pierr & purr & hrr & ronron & srr \\
\hline
\end{tabular}

Certainly, cats all over the world make pretty much the same noise when they speak. What makes the difference in these human translations, however, is how that noise was interpreted by speakers of the language. If you've spent significant amounts of time with people from other countries, you know that animals speak different languages too. Depending on where a chicken is from, for example, she might cluck-cluck, bok-bok, tok-tok, kot-kot or cotcotcodet. In the United States, however, animals speak English: Arf, baa, bark, bray, buzz, cheep, chirp, chortle, cluck, cock-a-doodle-doo, cuckoo, hiss, meow, moo, neigh, oink, purr, quack, ribbit, tweet, warble, etc.. Pandas coming back 
to China from either USA or Japan will take quite a long time getting used to Chinese nurses speaking Sichuan dialect for they either speak English or Japanese.

Since animals in different language communities speak differently, then how is it possible for interlingual translation? In language, animals carry bodily mimesis of a culture. It's not the natural animal that speaks in language but a semantic structure (phonetic sound and symbol), a communicative sign, conventionalized in a speech community through embodiment imitating the animal. When Chinese read "that cat meows", they will picture up a Chinese cat and go back to Chinese language system, saying 那只猫叫了(Nā zhī māo jiào le) instead of 那只猫喵了(Nā zhī māo miāo le), though "miāo" sounds close to cat's call and similar to English "meow". "Meow", an onomatopoeic word, as a communicative sign, imitates cat's call, but the same function can be played by non-onomatopoeic words as well. Embodiment tells us that any sound comes from actions. So in many cases, verb plays the function of onomatopoeic word intralingually and interlingually, and vise versa. For instances:
Diagram 6. Intralingually

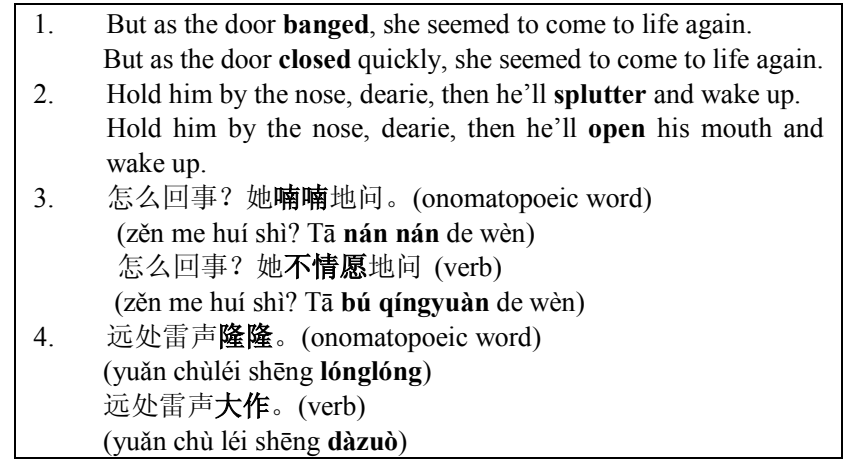

In Diagram 7, onomatopoeic words are translated into verbs and vise versa. Embodiment helps translators to anchor different communicative signs, interlingually, down to the same natural animal and make the translation negotiable.

Substitution of different embodiment (interplay of onomatopoeic word and verb) shows typical cross-modality.

Diagram 7. Interlingually

From onomatopoeic word to verb:

1. 小张呼噜了两声, 又昏过去了。xiăo zhāng hū lǔ le liăng shēng, yòu hūn guò qù le. Xiao Zhang made an indistinct noise and then fell unconscious once more.

2. 她的脸刷地红了。 tā de liăn shuā dì hóng le. Her face went red in an instant.

3. I clanked the kettle. 我敲水壸。wǒ qiāo shuǐ hú.

4. The train puffed toward Beijing from Shanghai. 火车从上海开往北京。huǒ chē cóng shàng hăi kāi wăng běi jīng.

From verb to onomatopoeic word:

1. 他把茶杯往桌上一顿。 tā bă chá bēi wăng zhuō shàng yī dùn. He slammed his tea cup down on the table.

2. 青蛙在郊外的田野里起劲地叫着。qīng wā zài jiāo wai de tián yě lǐ qǐ jìn dì jiào zhe. The frogs in the fields outside the town were croaking cheerfully.

3. Juan fell asleep almost immediately. 胡安几乎倒头就呼呼睡了。hú ān jī hū dăo tóu jiù hū hū shuì le.

4. John expected them to start brawling, but Mrs. Li merely laughed good-naturedly. 约翰以为她们要开始吵架了, 可李太太只是很和善地哈哈大笑了一阵。 yuē hàn yǐ wéi tā mén yào kāi shǐ chăo jià le, kě shì lǐ tai tai zhǐ shì hěn hé shàn dì hā hā dà xiào le ȳi zhèn.

Diagram 8. Faithful translation

\begin{tabular}{|c|c|}
\hline 春夜 & Spring Night \\
春宵一刻值千金, & A moment of spring night is worth its length of gold, \\
花有清香月有阴。 & When flowers spread on moonlight and shade fragrance could. \\
歌管楼台声细细, & The slender flute from the bower plays music slender, \\
秋千院落夜沉沉。 & The tender night on garden swing casts show tender. \\
苏轼 & Sushi (Tr. by Xǔ Yuānchōng, [8]:17) \\
\hline
\end{tabular}




\subsection{Volition Integration}

Cognition is neither observable nor effective unless it is linked to the body and to the physical world beyond the body. Importantly, the physical world has its own independent dynamics; it changes whether we want it to or not. The embeddedness of cognition resides in the interface between body and world. Each individual experience, each moment of wakeful living, changes us, at least a little. The power of individual one-time experiences to alter cognition has been experimentally documented many times. This review suggests that cognition just is an event in time, the emergent product of many heterogeneous systems bound to each other and to the world in real time. Yet embodiment anchors as well in presentation, which is neglected in cognitive linguistics.

Any text conveys communicative intentions of the author at the time he composes it. Moyan, winner of Nobel Price of Literature in 2012, said on a TV show that he broke down, time and again, in writing his Big Breasts and Wide Hips, for each time, picking up his pen, he would think differently. So is the case with text readings. Readers may either trace out the author's intention, conventionally, in the text, or they may figure it out the other way round, for embodied cognition changes in each reading. It's reader's volition which decides either to be with the author or to be himself in reading. However, translators do not enjoy this complete freedom, if they stick to form presentation in translation. Translators may read the text under the author's mercy and translate with intentionalized imitation so that the translated version can be "faithful" to the source text. For example, see Diagram 8.

But, if the author composes his text in an idiosyncratic way, intracultrally and interculturally, see Fig.1 and 2, translators have to translate with both change and embodied anchorage which resides in unique as well as conventional representation. Check the following examples.

Easter wings
Lord, who createdst man in wealth and store,
Though foolishly he lost the same,
Decaying more and more,
Till he became
Most poore:
With thee
Oh let me rise
As larks, harmoniously,
And sing this day thy victories:
Then shall the fall further the flight in me.
My tender age in sorrow did beginne:
And still with sicknesses and shame
Thou didst so punish sinne,
That I became
Most thinne.
With thee
Let me combine
And feel this day thy victorie:
For, if I imp my wing on thine
Affliction shall advance the flight in me
George Herbert

Figure 1. Carmen figuration
George Herbert's "Easter Wings" (Hiraga [4]) is written in a form of pattern poetry known as carmen figuration, otherwise known as shaped verse, in which the words and lines are arranged on the page so that they create a visual image or illustration of the poem's subject. In using shaped verse, the poet creates a visual image of wings. These wings, whether intended to be of angels or of birds, offer a thematic view of the human state. Additionally, as the poet progresses from the first stanza to the second, the nature of man also progresses from God's creation and the gifts provided therein to the fall of man and the required acceptance of Christ. In closing the poem, Herbert references wings, and the repair (healing) thereof to state that with help of God he can fly again and that his purposeful suffering will allow him to progress spiritually.

Sushi composed his poem in quite different figure. See fig. 2 .

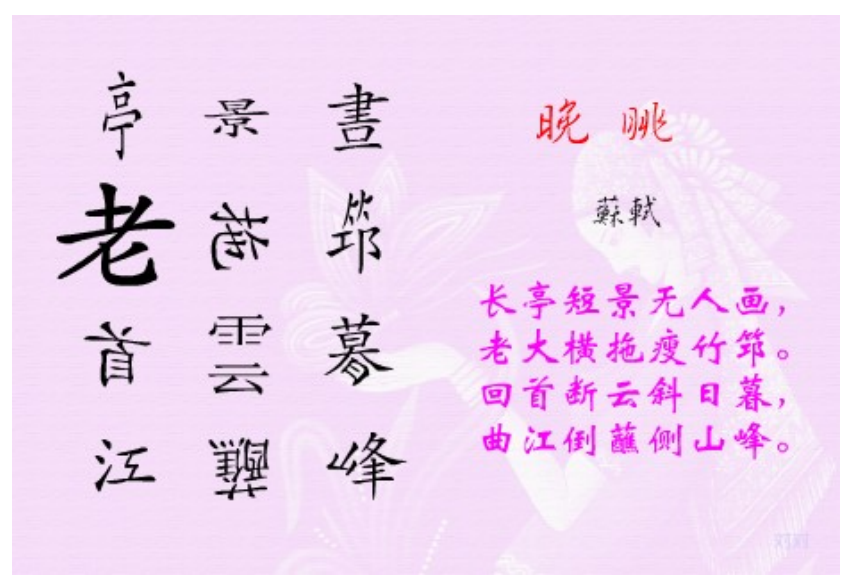

Figure 2. Poem made in Chinese characters

He imbedded his poem Dusk View (晚朓) in Chinese characters by writing each of them in different configurations. In left column above, he wrote 亭 in a long slim form to mean 长亭, literally long pavilion; and 景 in a flat form to mean 短景, narrow view; he omitted 十 in 畫 to mean 无人画 picture not drawn by man; Therefore he completed his first sentence (third line, right column above). By writing 老 in a larger bold character, he got 老大 old man; putting 拖 sideway, he made up 横拖 dragging; through writing the upper part of 筑 in a slim character, he formed 瘦竹䈃 a slim bamboo stick, the second sentence. Following suit, he composed a little poem of 4 lines with 7 characters in each, called 七绝. Yet he didn't write a complete sentence in each line, but only 3 characters in different configurations. It is reader's embodied cognition of Chinese characters that helps to form up a complete natural vision of an old man dragging a slim bamboo stick by the long pavilion with the sun setting on a mountain in silhouette inverted in a zigzag river in a cloudy dusk. Ideographic word formation makes possible the poem composition and therefore also anchors reader's cognition.

I may translate Easter Wings in the same form representation as source text, see Fig.3, but fail to translate Dusk View into English. Ideographic word formation never 
integrates with that of cuneiform word.

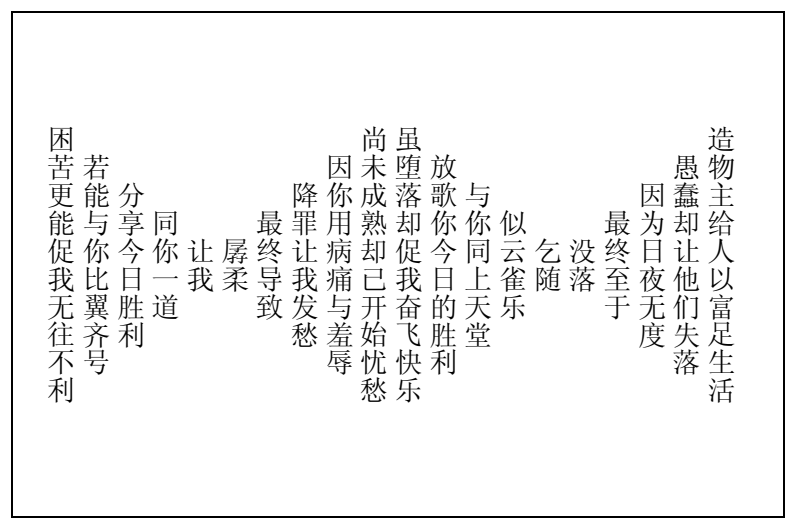

Figure 3. Chinese version of Easter Wings

It would be possible for translators to grasp the author's intentions, but almost impossible to translate in the same form completely: sentence structure, number of words, rhymes and meters. Translators have to integrate them in transformations in target text. As a matter of fact, it is no longer a translation proper but a rewriting. For the two poems are unique embodied cognition. From this, we can see that embodied cognition anchors as well as changes dynamically.

\section{Concluding Remarks}

Embodied cognition is a dynamic process and one-time perception and conception in language communication, yet conventional and unique representations anchor reading and translating in the way of 1). They perspectivize reading and translating in image schema and syntax; 2). They integrate mimetic schema in translating through mimetic representation, communicative sign function, volition and cross-modality.

\section{Notes}

Chinese reading of Diagram 8, Fig.2 and 3.

Diagram 8
春夜
春宵一刻值千金，
花有清香月有阴。
歌管楼台声细细,
秋千院落夜沉沉。

\begin{abstract}
chūn yè
chūn xiāo yīkè zhí qiān jīn gē guăn lóutái shēng xì xì qiūqiān yuànluò yèchénchén
\end{abstract}
huā yǒu qīngxiāng yuè yǒu yīn

Fig. 2
晚眺
长亭短景无人画, 老大横拖瘦竹籗。 回首断云斜日暮, 曲江倒蘸侧山峰。

wăn tiào cháng tíng duăn jǔng wú rén huà lăo dà héng tuō shòu zhú qióng huí shǒu duàn yún xié rì mù qŭ jiāng dăo zhàn cè shān fềng
逾越节之翼

yú yuè jié zhī yì

造物主给人以富足生活 zào wù zhǔ gěi rén yǐ fù zú shēng huó

愚蚟却让他们失落 yú chŭn què ràng tā mén shī luò

因为日夜无度

最终至于

没落

乞随

似云雀乐

与你同上天堂

放歌你今日的胜利

虽堕落却促我奋飞快乐

yīn wéi rì yè wú dù

zuì zhōng zhì yú

mò luò

qǔ suí

sì yún què lè

yǔ nǐ tóng shàng tiān táng

fàng gē nǐ jīn rì de shèng lì

suī duò luò què cù wǒ fèn fêi

kuài lè

尚未成熟却已开始忧愁

因你用病痛与羞辱

降罪让我发愁

最终导致

孱柔

让我

同你一道

分享今日胜利

若能与你比翼齐号

困苦更能促我无往不利

shàng wèi chéng shú què yǐ kāi shǐ yōu chóu

yīn nǐ yòng bìng tòng yǔ xiū rŭ jiàng zuì ràng wǒ fã chóu zuì zhōng dăo zhì chán róu ràng wǒ tóng nǐ yī dào fên xiăng jīn rì shèng lì ruò néng yŭ nǐ bǐ yì qí hào kùn kǔ gèng néng cù wǒ wú wăng bù lì

\section{REFERENCES}

[1] Blackmore, Susan. The Meme Machine. London: Oxford University Press. 1999.

[2] Han Shihui \& G Northoff. Culture-sensitive neural substrates of human cognition: a trans-cultural neuroimaging approach. Nature reviews $\mid$ neuroscience. Vol. 9. Macmillan Publishers Limited. 2008, PP. 646-654.

[3] Hawkes, David \& J Minford. The Story of the Stone. London: Penguin Books. 1973, P.5.

[4] Hiraga, Masako K. Metaphor and Iconicity. New York: Palgrave Macmillan. 2005, PP. 58-63.

[5] Johnson, Mark. The Body in the Mind. Chicago: University of Chicago Press. 1987.

[6] Joly, H Bencraft. The Dream of the Red Chamber. Singapore: Tuttle Publishing. 2010, P.4.

[7] Wang, Bin. Image Schematic Account of Translation. Hermeneus. Revista de la Facultad de Traduccio'n e Interpretacio'n de Soria (9). 2007, PP. 207-219.

[8] Xu, Yuanchong. Selected Poems of Sushi. Changsha: Hunan People's Publishing House. 2007, P.17, P.193.

[9] Yang, Hsien-Yi \& Gladys Yang. A Dream of Red Mansions. Beijing: Foreign Languages Press. 1994, P.4.

Fig. 3

[10] Zlatev, Jordan. What's in a schema? Bodily mimesis and the grounding of language. In: Beate Hampe (ed.), From 
